Bogen virker som en veloplagt diskurs af en meget vidende foredragsholder. Som introduktion til et dybere studium af de nævnte sammenhænge kan den nok være interessant, men bestemt ikke som mappetitvækker « til et studium i Grundtvig. Dertil er den for forhastet i sine linjeføringer. Grundtvigs tankegods behøver ikke denne voldsomme omklamring af moderne tænkning for at kunne legitimere et engagement.

\title{
Grundtvig og hans virkningshistorie til international debat
}

\section{Af Vagn Wahlin}

Om Paul Röhrig (ed.) «Um des Menschen willen - Grundtvigs geistiges Erbe als Herausforderung fur Enwachsenenbildung, Schule, Kirche und soziales Leben*, s. 1-336, Deutscher Studien Verlag. Weinheim 1991. ISBN 3-89271-252-2

Grundtvig - kulturelle og sproglige oversattelsesproblemer $i$ og uden for Danmark

Grundtvig er uden for Danmark langt mindre kendt end hans samtidige, Kierkegaards, men har for det danske åndsliv og samfundsliv i bredere kredse haft nok så stor betydning. Man har bl.a. set den manglende internationale interesse for denne åndskæmpe som et udtryk for, at Grundtvig var så specifik dansk, at han næppe har meget at sige fremmede. Enhver, der har prøvet at oversætte Grundtvig, vil vide, at dette næsten uoversættelige danske ved ham findes ikke blot i det særegne ved sprogtone og ordforråd i hans poesi og prosa, men også $\mathrm{i}$ hans bagved liggende begrebsapparat og tankestruktur. Tilsvarende er $\mathrm{fx}$. højskolens ide og praksis meget vanskelige at forklare for mennesker med fremmed kulturbaggrund - højskolen skal ses og opleves. Samtidig er det værd at erindre sig, at Grundtvig også forekom mange af hans samtidige danske akademikere nasten uforståelig eller urimelig egenartet i sin sprogbrug, kulturforståelse og folkeopfattelse.

Grundtvig og det grundtvigske er ikke lette at kapere og var i hans samtids Danmark for mange ikke umiddelbart tilgængelige ${ }^{l}$. Han skabte i bevidst opposition til de dannede lags kulturdominans og sprogstil den $»$ folkeligt danske tone*, som først for alvor i slutningen af 19. århundrede via skolesystemerne og sangtraditionen m.v. er blevet optaget som en uafrystelig del af den danske setvforståelse i brede kredse.

Mange fra den ærke-københavnske befolkningsdel, som jeg tilhører, måtte dengang og idag først ved hårdt arbejde senere $i$ livet lære sig at læse og forstå ๓grundtvigsk $\alpha$. Den københavnske akademikerelites nedarvede anti-folkelighed i grundtvigsk forstand faldt mig og mange af mine medstuderende helt naturlig, 
og vi følte os langt mere på linie med tankegange og sprogbrug i angel-saxiske og tyske universitetsmiljøer end med danske højskoletraditioner, folkelig fællessang og dansk foreningsliv. Også vi fra det københavnske akademikermiljø såvel som mange fra de nye urbane områder og de københavnske arbejderkvarterer havde og har et noversættelseseproblem $*$, som gør det relativt nemt for mig at forstå, hvorfor Grundtvig og det grundtvigske er så svært tilgængelig for angelsaxere, tyske og franske m.fl.

Der fremtræder over store dele af verden i disse år en voksende erkendelse af, for det første, de nationale ejendommeligheders fortsatte store betydning (jvf. Østeuropa og Balkan), for det andet, sprogets og den ikke-centraldirigede oplysnings fundamentale rolle for personlig, lokal og national identitetdannelse, og for det tredje, samspillet mellem religiøs livsholdning, national identitet og menneske-forståelse. Med baggrund i disse fundamentale interessefelter kan der $i$ de seneste år iagttages en stigende international optagethed af Grundtvigs tænkning og virke samt parallelt hermed en interesse for, hvorledes det grundtvigske er slået igennem som en stadigt engagerende indelig anv og social praksis i Danmark og andetsteds, dvs for Grundtvigs virkningshistorie.

Her indledningsvis vil jeg vedrørende forholdene uden for Norden fremsætte den påstand, at interessen for Grundtvig i bredere internationale kredse end de snævrest forskningsmæssige miljøer hænger direkte sammen med Grundtvigs virkningshistorie først og fremmest i det egentlige Danmark, men også fx i norsk højskoleliv. Hvis ikke højskolerne, mange efterskoler og friskoler, den kirkelige grundtvigianisme, den nationale danskhed med - trods alle lokale problemer med indvandrere og flygtningen $i$ dag en reel respekt for mindretallenes rettigheder m.v. havde været så synlige og i det store hele virksomme i den danske sociale og åndelige virkelighed, så ville udlandet $i$ dag mere end 100 år senere ikke med urette have set Grundtvig, som det han også er: denne mærkelige dansker, der for sin samtid og for sin eftertid har været så vanskelig at sætte i bås og begribe og i Danmark dog ikke er til at komme uden om. De udenlandske ville antagelig da have sluttet sig til en af Grundtvigs samtidige herhjemme, som bemærkede, at han havde det med Grundtvig som med de vilde dyr: Det var interessant at sådanne fandtes, men dog glædeligt, at man ikke skulle pleje omgang med dem.

Det har været et af de nye århusianske „Grundtvig-Center «s opgaver at opfange og formidle denne voksende internationale interesse bl.a. ved at arrangere internationale konferencer og ved et forskningsinitiativ som „Grundtvig og England.

Det er i denne sammenhæng glædeligt, at Kölns Universitet som en del af dets omfattende 600 års jubilæumsfestligheder trods forståelsesproblemerne omkring Grundtvig fandt det relevant at gøre »den gamle« og hans virkningshistorie til hovedtema ved én af jubilæumsaktiviteterne med en tre dages velbesøgt international kongres september 1988. Kongressen afholdtes passende på Kolner Volkshochschule under forsæde af professor i pædagogik, Paul Rohrig, og med over 200 deltagere vasentligst fra de tysktalende områder, men med en virkelig international vifte af foredragsholdere. Konferencen blev særdeles vel dækket af medierne og til glæde for et bredere internationalt publikum udkom indlæggene på tysk i bogform i en stramt redigeret fremlæggelse i 1991. 
Bogen er tematisk opdelt i 3 hovedsektioner om I. pædagogik og voksenuddannelse, II. theologi og religionspædagogik samt III. nordisk filologi; hovedsektionerne var delt i 8 undersektioner og dækket af 37 hovedindlæg (heraf 5 indledende fællesforedrag, inden man gik i sektioner), der sammen med de 20 debatreferater dokumenterer dels konferencens høje faglige niveau, dels den store bredde $\mathrm{i}$ interessefladen for Grundtvig og hans virkningshistorie både tematisk og nationalt set ud fra foredragsholdernes og forfatternes baggrund og oplæg. Hoved- og undertemaer samt de enkelte foredrag/artikler og diskussionsreferater kædes til stadighed sammen af et ønske om at synliggøre samhørigheden dels mellem videnskab og praksis, dels mellem menneskesyn og sociale handlinger.

Hovedredaktøren, professor em. i almen pædagogik, Paul Röhrig, fra Kølns universitet og hans medredaktører har stor ære af at have fået godt styr på de mange bidrag og debatreferater. Nogle indlæg er forsynet med klassisk akademisk noteapparat, andre er gengivet i det mundtligt holdte foredrags friere form. Her vedrørende bogens opbygning og form må jeg komme med et par hjertesuk:

For det første, der savnes en bibliografisk korrekt og samlet litteraturliste bagi, hvor al i noter og tekst anført litteratur er gengivet, så læseren selv kan bestille interessant litteratur uden at skulle blade baglæns gennem et hav af noter med hemmende notationer som "A.a.O., Dass., SW XXIX,332 etc. for endelig at finde originalen.

For det andet, siderne er så mættet med tekst, at øjet har svært ved at følge de lange og tætstående linier med over 4000 typeenheder pr. side. Omsat til mere normal sidestørrelse vil det sige, at bogens 336 sider reelt svarer til ca. 550 sider.

Den ofte komprimerede tekst uden fyldekalk gør bogen til en i både omfang og indhold særdeles vægtig fremlæggelse. Noterne er læservenligt trykt nederst på siderne og dispositionsmassigt er bogen klart bygget op og overskuelig.

Den store spredning i emner og $\mathrm{i}$ forfatternes baggrund gør det ikke muligt at gennemgå alle artikler eller at yde alle interessante bidrag den fortjente opmærksomhed. Vedrørende de mange danske bidrag vil læseren kunne finde hovedsynspunkterne andetsteds $\mathrm{i}$ forfatternes danske arbejder ved hjælp af følgende stikord fra titler og emner:

Poul Engberg (Folkeligheden - nationale, sociale og demokratiske træk i G.s tankeverden), Kaj Thaning (Menneske først), KE. Bugge (Grundtvigs pædagogiske grundtanker, Jens Gron (Folkehøjskolens udvikling), J. Krøgholt og $A$. Andrésen (Højskolens praktiske organisation, elevmasse mv), Hans Henningsen (Højskolen mellem G.s ideer og den moderne verdens krav), Knud Amfred (Liv og opdragelse i et grundtvigsk hjem), Jakob Andersen (En skole for livet ... efterskolen), Ebbe Klovedal Reich (Grundtvig, højskolen og kvindernes frigørelse), Henrik Yde (Folkehøjskolen og arbejderbevægelsen), Inken Meinertz (Folkehøjskolen og den kvindelige arbejderbevægelse), Christian Thodberg (Det levende ord), Theodor Jørgensen (Folk og folkekirke hos Schleiermacher og Grundtvig), Gunther Weitling (Religionsundervisning i følge Grundtvig), Hans Bekker-Nielsen (Skabeisen af et færask skriftsprog), J.P. AEgidius (Mytefortælling 
i højskolen hos Grundtvigs efterfølgere), Fl. Lundgreen-Nielsen (Grundtvig som digter mellem oplysning, romantik og kristendom).

I det følgende har jeg fundet for et dansk publikum mest interessant at holde mig til et udvalg af de ikke-danske bidrag; men igen har jeg måttet foretage en indskrænkning ud fra højst subjektive principper, for dog at kunne få plads til at sige noget udover det rene referat.

\section{Erica Simon - Grundtrig $i$ et udvidet perspektiv}

Med imponerende overblik og engagement fører den (nyligt afdøde, jvf. nekrologen) ledende franske grundtvigforsker og højskolekvinde, Erica Simon, læseren gennem væsentlige sider af Grundtvigs tænkning og arbejdsliv, men fremhæver for os, at det centrale ligger i hans virkningshistorie og i pædagogikken og frem for alt i arven i folkehøjskolen. Grundtvig er den ene af tre danske af verdensomfattende betydning, men må dog efter hendes mening placeres efter Kierkegaard og H.C. Andersen. Uden for Danmark er det den stadigt sprællevende højskole $\mathrm{i}$ dens idelige kriser og tilpasninger til skiftende tiders behov, som er inspirerende og anvendelig langt uden for det dansk-nordiske rum - ikke blot i den vestlige verden, men også i Asien og Afrika.

Grundtvigs ikke-akademiske forståelse af en højskoles funktion og nytte får Simon til at fastholde det danske ord nhøjskole " såvel på fransk som i den tyske tekst, ligesom jeg har bemærket, at mange af forfatterne senere i bogen springer over problemet med det uoversættelige i Grundtvigs tankeverden og benytter rent danske ord som »folkelighed m.v. bragt efter citater direkte på dansk $\mathrm{i}$ den tyske tekst.

Grundtvig var efter Simons mening bange for, at den historisk i folket bredt bevarede kultur skulle gå tabt over for akademikernes elitære, tysk og romersk påvirkede tankeverden og kulturforståelse. Som modideal hertil stillede han den islandske kultur, hvori det norrøne element var lyslevende. Vasentligt for at undg̊̊ faren for chauvinisme er, at det nationale hos Grundtvig blev set i vekselvirkning med det overnationale, det universelle. Det videnskabelige måtte have det folkelige som forudsætning, mener Grundtvig iflg. Simon, hvis ikke fornuften i opłysningstidens forstand skulle gøre sig til sit eget formål. I sidste ende skulle det samlede skolesystem fra barneskolen over højskolen til den nordiske videnskabelige højskole $\mathrm{i}$ Göteborg tjene „Livets Tarv $\mathrm{i}$ det medmenneskelige og i det samfundsmassige, mens det praktiske skulle læres i arbejdslivet. Grundtvig opstillede således, efter Simon, et totalt dannelsesprogram, hvor det centrale ikke var gennem uddannelsen at skabe intellektuelle, der blev fremmede for deres lokale miljø og udgangspunkt, men tvært imod var at føre en åndelig dimension ind $\mathrm{i}$ hverdagslivet og $\mathrm{i}$ arbejdslivet for brede lag af befolkningen og især for gårdmandsklassen (s. 23).

Simon fremhaver, at det grundtvigske institutionelle koncept ikke blev fulgt i den pædagogiske praksis, hverken fra centralt hold eller fra mere folkelig side. Men fra 1860erne blev i den agrare verden de mange bondehøjskoler og folkehøjskoler udover landet de sejrende $i$ en regulær kulturkamp med de herskende kulturstrømninger i København især fremført dér af den akademiske elite. 
Omsat til vor tids sprogdragt og åndelige strømninger ser Simon megen lighed mellem Grundtvigs folkelighed og den nationale of personlige identitetssøgen $i$ mange tredje-verdenslande, $i$ minoritetskulturer $i$ Europa samt $i$ den katolske kirkes erkendelse af den ægte tros nødvendige samspil med det nationale i sprog og kultur $\mathrm{i}$ det hun med et moderne begreb kalder winculturation $\alpha$. Vigtig $i$ denne forståelsesramme er her den kulturelle bevægelse nedefra og op, dvs ikke elitens påtrykning nedad i samfundet af sine kulturformer, men den brede befolknings erkendelse af og kamp for egne kulturværdier i en løbende vekselvirkning med elitens eller importerede kulturstrømninger, - at man her kan tage en diskussion om kontakt og påvirkning i nutiden mellem populære kulturflader på tværs, fx mellem rock-musikkens og TVs internationalisering uden om og bag om kultureliterne og de i grundtvigsk forstand folkelige kredse og institutioner, ændrer ikke ved iagttagelsens relevans. I det næunte engagement nedefra forstår hun mange danske højskolers og grundtvigskes kamp mod EFs elitære centralisering af politik og kulturformer. Med folkeafstemningerne om Masstricht-traktaten juni 1992 og maj 1993 in mente er det af Simon en næsten profetisk udlægning i 1988 af en af siderne af folkelighedens moderne engagement i 1990ernes Danmark.

Ad den vej kommer Simon sluttelig ind på, at ægte folkelighed altid vil være næst beslægtet med oprør. Oprørets form kan ikke forudsiges, men vil være et løbende opgør med enhver form for elitær eller centraliseret styreform eller med en rendyrket rationalitet som uden at søge og følge befolkningens dybtfølte krav om rimelighed, medbestemmelse, overskuelighed og medmenneskelig grundholdning vil presse de styrendes supermodeller ned over befolkningen.

I et senere indlæg (p. 200) følger hun tanker herfra op omkring værdien af Grundtvigs folkelighedsbegrebs anvendelse i den tredje verden, hvilket konkretiseres ved en parallelisering til »négritude $«$-holdningen i Senegal.

\section{Grundtvig og tidlig tysk national og romantisk filosofi}

Grundtvig var $i$ udviklingen af sit folkelighedsbegreb påvirket af tysk tænkning fra Herder og Fichte m.fl. formidlet bl.a. via Heinrich Steffens. Betydningen af Herders virke for den tysk-nationale udvikling op til o. 1770 fremlægges overskueligt af Oto Dann, der tillige er den særdeles kyndig bidragyder til den moderne nationalismeforskning. Herder og bevægelsen havde en dobbeltorientering (s. 44), dets en patriotisme i relation til den konkrete stat, der skaffede orden og embede, dels en fællesskabsfølelse i forhold til det større tyske faedreland, som man tilherte gennem sprog og kultur. Den tidlige tysk-nationale bevægelse havde social baggrund blandt yngre dannede fra borgerskabet og stod således i modsætning til det hidtil ubestridt førende og statsbærende aristokrati med dels dets familiemassige baggrund i godsbesiddelse, dels dets internationale kulturbaggrund (og ofte fransk omgangssprog) i den franske oplysningstid.

Hvad «tysk « egentlig var for noget stod ifølge Dann endnu 0.1800 ikke helt klart, men fire hovedelementer indgik deri: (1) man havde højtysk skriftsprog fælles, (2) engelsk og nordiske sprog og kultur var acceptable som dele af den fælles germanske fortid i modsætning til romansk og fransk påvirkning, (3) 
daglig-talesproget hos de socialt laverestående befolkningslag med sociale og lokale varianter var ikke værdsat, men oversat til højtysk var der folkeligt arvegods at hende nedefra, (4) rigsområdet (Det Hellige Romerske Rige af Tysk Nation) blev det fælles geografisk-politiske rum. - Der var tale om primært en kulturel-litterær bevægeise, der dog havde klare politiske ansatser gennem etableringen af den offentlighed via klubber og tidsskrifter m.v. Borgerlige frihedsbegreber blev formidlet og forbundet med en national enhedstanke byggende på fællesskab i historie, kultur og sprog.

Den efterfølgende diskussion (s. 53-54) afslørede den mentale berøringsangst, som »nationalisme $*$ og $»$ folk endnu har i tysk kulturdebat efter nazismens excesser. Heroverfor blev modsætningsvis netop de etiske og medmenneskelige dimensioner i Grundtvigs folkelighedsbegreb betonet.

\section{Grundtvigs paedagogiske tankning og de tyske voksenuddannelser}

Efter præsentationer af forskellige sider af Grundtvigs pædagogiske tænkning og folkehøjskolens udvikling og indsats set som en væsentlig side af den grundtvigske virkningshistorie blev det $\mathrm{i}$ et diskussionsindlæg af de ikke-danske fremhævet, hvor bevidst man i den danske tradition var ikke blot om betydningen af folkets historie, men også om højskolens og den pædagogiske tænknings og udviklings historie. Endvidere hæftede man sig ved den til stadighed gennem mere end 150 år udbredte og fagligt dybtgående pædagogiske debat i danske skolemiljøer, offentlige som private.

I tysk pædagogisk virksomhed var pædagogikkens tankesæt uden større historisk dimension (s. 82-83). Af bemærkningerne må man kunne drage den slutning, at pædagogiske begrebssæt og praksis i den tyske undervisnings dagligdag ofte fremtræder over for pædagogisk helhedstænkning som lærere ved et tagsetv-bord, hvor der nuppes en bid her og en teknik der uden dybere overvejelser over, at elementernes anvendelighed i skolestuen i høj grad afhænger af deres historisk-sociale og kulturelle kontekst. En følgende diskussion (s. 100) viste interessen for betydningen af det ideologiske klima for andre udbredte voksenuddannelsestilbud (folkeoplysningsforbundene, folkeuniversitetet m.v.). De ikke-danske så et positivt samspil omkring uddannelserne $i$ en bredere offentligheds interesse derfor i Danmark, men undredes samtidig over, at $\mathrm{fx}$ arbejderbevageisens uddannelsesformer ikke på mere markant vis var inde $i$ den danske debat. Diskussionen problematiserede endvidere om og hvordan det grundtvigste of folkehøjskolens koncept kunne nyformuleres over for den moderne undervieningsteknologi (s. 106-07), hvor det menneskelige og det levende, talte sprog er blevet stadigt mere tilsidesat i effektivitetens og eksamensfixeringens navn.

Denne relevante problematisering fra de udenlandske iagttagere var i forskellige varianter en gentagen påpegning af, hvor meget friere og mere fleksibelt og padagogisk effektivt det danske system faktisk var i forhold til de fleste andre steder. Dette særpræg skulle sikres og bevares, for at Danmark kunne fungere som et pædagogisk og uddannelsesmæessigt laboratorium, hvor et frugtbart, levende og stadigt foranderligt vekselspil mellem teori og praksis kunne iagttages 
af ikke-danske med henblik på tilpasning af visse teorier og praksisser efter den lokale kontekst og historie $\mathrm{i}$ iagttagernes hjemlande.

Ud fra sådanne påpegninger og advarsler kan man som dansk universitetslærer og mangeårig forsker $i$ sider af det frie danske skolesystem ${ }^{2}$ ikke undgå at få pirket til nogle fæle mistanker vedr. visse danske politikeres og især undervisningsministeriets næsten maniske hang til at ville indrette danske læreanstalters virke efter udenlandske forbilleder og med udenlandske kontrol-paneler. I stedet burde vore styrende - som fx franskmændene energisk gør i en bevidst elitær kultureksport - indadtil varme om det notorisk bæredygtige (dokumenteret nu i utallige rapporter også af udenlandske iagttagere) fra barneskolen til universitet i dansk uddannelse og udadtil saelge til udlandet netop det positive $i$ dansk tradition omkring bl.a. en udstrakt pæedagogisk metodefrihed og omfattende frihed til faglig indholdsfastlæggelse og en udbredt vekselvirkning mellem teori of praksis. Det sidste findes fx på universiteterne $\mathrm{i}$ forholdet mellem forskning og undervisning, hvor ministeriet nu helt har afskaffet de økonomiske forudsætninger for denne sammenhæng og i folkeskolen tidligere med udstrakt offentlig støtte til mange forsøgsordninger og til videreuddannelser af lærerne på Lærerhøjskolen. - At magtglade politikere i ideologisk enøjethed eller i bagudbøjet benovelse over halvtfordøjede hasteindtryk fra visse eliteinstitutioner i det store udland gerne vil styre udviklingen, og at embedsmænd gerne vil ensrette og bureaukratisere, skal man vel i danske uddannelser på alle planer ikke undre sig over, blot indædt og udholdende bekæmpe vedr. det $i$ forhold til dansk tradition ubrugelige eller direkte skadelige og gå i dialog vedr. det evt. brugelige. At politikere $\mathrm{i}$ deres tidnød til orientering og bureuakrater af mangel på visioner skulle kunne finde noget $i$ den danske sammenhæng brugeligt fra udlandets pædagogiske debat og praksis, som ikke forlængst via den udbredte, mangesidede og åbne danske pædagogiske debat er introduceret af uddannelsessystemerne setv, kan dog stærkt betvivles. Men moderne central styring via elektronisk budgetkontrol har gjort kampen på de indre system-linier i Danmark ulige vanskeligere end tidligere. At danske skoleinspektører i folkeskolen nu fra 1993

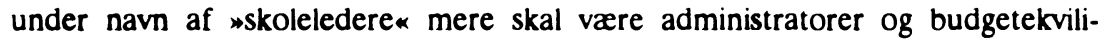
brister end pædagoger er blot én blandt mange konsekvenser af de senere års uhellige alliance mellem visse politikere og bueraukraterne $i$ et fælles angreb på netop dén frodige pæedagogiske og skolemæessige uregerlighed, som er en logisk og positiv følge af vor - omend nu beklippede - arv fra det grundtvigske folkelige og predagogiske frisind.

Martha Friedenthal-Haase sætter i sin artikel fokus på Grundtvig i den tyske debat $1933 \mathrm{om}$ votsenuddannelse. Det er for en dansk interessant at erfare, hvordan det nazistiske styre så hurtigt fik sat sig på den almene meningsdannelse, at det afgørende kom til at præge også denne ellers ret specielle debat. Grundtvigs tanker om frihed gled man udenom, men hans folkebegrebs og kristendomsbegrebs sammenhæng med den pædagogiske tænkning og praksis hos ham og i højskoten var mere acceptable (s. 113).

Norbert Vogel har et længere tidsperspektiv end førnæunte forfatter i sin artikel (s. 117) om oprindelsen til Grundtvig-receptionen i tysk folke- og voksenuddannelse. Påvirkningen startede allerede i 1860erne og følges af Vogel til 1910, hvor det særligt var den danske debat og praksis omkring folkehøjskolen, 
som fik direkte betydning for den tyske "Volkshochschul-Bewegung", som tillige var påvirket fra den engelske udvikling omkring "University Extension «. Grundtvig selv forblev mindre kendt, bl.a. fordi der manglede oversættelser til tysk af hans centrale arbejder. Det frie nordiske bondearistokrati, de relativt lavere sociale spændinger i Danmark og samspillet mellem disse forhold og kooperationens økonomisk effektive landbrug gjorde trods spændingerne omkring Slesvig danske og nordiske forhold kendte og populære i borgerlige tyske kredse omkring århundredskiftet. Også kendskabet til nordisk kunst og litteratur var udbredt, og dette nordiske kulturliv var i disse kredse i høj kurs fra 1890erne (s. 120). Grundtvig blev da også langsomt mere kendt, men ofte på anden hånd og mestendels i det pædagogiske interessefelt med baggrund $i$, at en række Heimvolkshochschulen med tysk kulturbaggrund oprettedes kort efter 1900 i SlesvigHolsten og andetsteds. I 1908 kunne der således holdes det tredje tyske folkehøjskolemøde i Dresden.

I 1909 udkom med flere senere oplag A.H. Hollmanns bog på tysk om "Den danske Folkehøjskole og dens Betydning for Udviklingen af en folkelig Kultur $i$ Danmark« (da. udg. 1910). Bogen blev i løbet af kort tid oversat til engelsk, hollandsk, russisk, finsk, polsk, serbo-kroatisk og japansk. Herved slog højskolen og delvis Grundtvig for alvor igennem internationalt især vedrørende samspillet mellem voksenuddannelse, national kultur og folkehøjskolen som en del af det åndelige grundlag for et folkeligt, politisk demokrati, jvf. også fremhævelsen deraf $i$ undertitlen på 1919 udgaven af Hollmanns bog (s. 125).

Om den tyske folkehøjskoles praksis viser Herman Scheile, at trods en vis reverens for Grundtvig, så har man ikke indoptaget Grundtvigs menneskesyn, ej heller hans forståelse af folkelig oplysning og heller ikke grundopfattelsen om åndelig frihed. Det stikker ifølge Scheile dybt $i$ den tyske opdragelsestradition, at de unge skal formes og dannes efter en plan lagt af dem, der ved bedre, som bygningshåndværkeren må følge arkitektens tegning. Derved bliver for Scheile ægte frihed og vekselvirkning i dannelsesprocessen umuliggjort. Man kan, mener han, ikke programmere det frie, demokratiske menneske. Det fremstår netop kun af fri og levende veksetvirkning mellem mennesker, der grundlæggende har samme være, som det lidt bittert-ironisk konstateres (s. 133). Friheden og respekt for livets foranderlighed og risici vil og kan det tyske system som sådant ikke imødekomme, heller ikke i Heimvolkshochschulverdenen (s. 136-37). Heroverfor stiller Scheile Grundtvig selv, der levede med denne løbende usikkerhed - hos ham var det ikke tom snak. Dette ret triste billede blev delvis tilbagevist i den efterfølgende diskussion, men alligevel står det klart, at de tyske folkehøjskoler mere har tilknytning til den tyske pædagogiske tradition end til Grundtvigs og den danske højskoles ofte radikale visioner.

Paul Rohrig lagger i et tankevækkende indlæg op til at forny en dialog mellem danske og tyske voksenuddannelser. ROhrig giver nogle fine eksempler til støtte for Grundtvigs ofte udtrykte frygt for samspillet mellem spekulativ filosofi og den sorte skote samt vedr. hans præcisering af hovedmodsætningen mellem *Liv og Dodx. en række helt parallelle problemstillinger og målsætninger til de grundtvigske fremheves i debatten fra tysk side under Weimar-republikken, men glider ud af interessefeltet grundet en forgrovet forståelse og direkte forveksling af grundtvigsk og nazistisk tankegods (s. 144). At fortælle tyske seminarieelever 
om, hvad højskolens virkelighed er, er næsten umuligt, men otte dages besøg på en dansk højskole æendrer helt opfattelsen hos de unge tyskere.

Man véd, konstaterer Rőhrig, i Danmark og Tyskland alt for lidt om hinandens pædagogiske og kulturelle tænkning og om muligt endnu mindre om virkeligheden vedr. hinandens voksenundervisning. Men, fremhæves det videre, for at en dialog skal blive nyttig, må begge parter vide, hvor de selv står, og hvad de setv mener. Det er endvidere for en dansk-tysk dialog et problem, at der faktisk ikke findes nogen fælles forståelsesramme $\mathrm{i}$ tysk voksenundervisning. Her må anmelderen tilføje, at i Danmark er metodefrihed mv og en evigt løbende pædagogisk debat et forvirrende udgangspunkt for en dialog. Nok kan de ydre rammer ( $\mathrm{x}$ økonomi og lovgivning) i Danmark forklares, men mlivet « $\mathrm{i}$ undervisningens hverdag er jo netop så grundtvigsk mangfoldigt og forskelligt $\mathrm{i}$ form og indhold, at det ikke som udgangspunkt for en dialog lader sig sætte på formel $i$ klare begreber - og vel heller ikke efter min mening skal det.

Sluttelig peger Rơhrig på, at ikke blot danske og tyske, men hele menneskeheden står over for menneskeskabte udfordringer på "Liv og Død« i økologien, i forureningen osv. Her skal og må dialogen, det levende ord og det medmenneskelige ansvar med ind i voksenundervisningen, for ellers tager formålsrationaliteten og den moderne informationsindustri magten ud af hænderne på de befolkninger, som skal leve og dø med den menneskeskabte virkelighed.

Eckhard Bodenstein giver en forbilledlig klar og informationsmættet fremstilling af de frie skolers (friskoler, efterskoler, højskoler) placering og betydning $\mathrm{i}$ den danske skoleverden. Staten betalte i Danmark til $199280-85 \%$ af udgifterne (nu et nedsat beløb) for de frie skoler, hvis virke bl.a. fungerer som en løbende udfordring for og korrektiv til det offentlige skolevæesen. Denne statsstøtte også til »kritiske skoler vises at være en arv fra det bedste $\mathrm{i}$ dansk liberalitet og fra Grundtvigs og Kolds tænkning og virke.

\section{Højskolen og Grundtvig i Afrika og Asien}

Dele af den grundtvigske arv har betydning for voksenundervisningen i Afrika og Asien i dag, hvilket demonstreres gennem flere indlæg.

I kølvandet på Koreakrigen i begyndelsen af 1950erne formidlede det DanskKoreanske Venskabsforbund en oversættelse af Grundtvigs tanker om folkelighed og identitetsskabende undervisning wfor livet火. Prof. Ok-Bun Lee viser (s. $206 \mathrm{f}$, hvorledes disse tanker var medvirkende til at skabe den sydkoreanske «nye landsbybevagekse, der skulle engagere de $80 \%$ af befolkningen, som endnu i 1950erne levede på landet, til en nødvendig modernisering af samfundet både materielt og åndeligt. Landsbyerne og bønderne skulle hjælpes til at tro på sig selv of til selv at tage hånd $\mathrm{i}$ hanke med moderniseringen. Fra 1970erne er det $\mathrm{i}$ høj grad lykkedes at mobilisere de $\mathbf{3 3 . 0 0 0}$ landsbyer. En ny arbejdsmoral er slået igennem, idet foragten for legemligt arbejde er forsvundet $i$ forbindelse med, at forholdene $\mathrm{i}$ den materielle basis og levevilkårene $\mathrm{i}$ det hele er stærkt forbedret. Med noget mindre held har man forsøgt at introducere ideerne i byerne og $\mathrm{i}$ den moderne industriproduktion. På det materielle plan og vedrørende faglig formidling samt vedrørende en forståelse af, at befolkningen setv kan virke konstruktivt i udviklingen, er meget nået, men udenadslære og tilbagehol- 
denhed over for egentlig dialog og debat præger stadig holdningen $\mathrm{i}$ den $\mathrm{i}$ landdistrikterne udbredte aftenskoleundervisning for voksne. Der er stigende forståelse for betydningen af samspillet mellem demokrati, selvbevidsthed, selvorganisering, kritisk sans og respekt for modersmålet og for landbokulturen; men det tager tid, anfører Lee, at få disse dimensioner med i den trods al højteknologi traditionelle sydkoreanske dagligdag.

Professor Sri N.K Mukherjee (s. $210 \mathrm{f}$ ) fra det af den store indiske digter, filosof, pæedagog og humanist Rabindranath Tagore grundlagte universitet, VisvaBharati i Indien, fremhæver de mange (bortset fra de kristelige) lighedspunkter mellem Grundtvigs og Tagores tankeverden, menneskesyn og samfundsforståelse.

Påvisningen af disse ligheder kan føres helt tilbage til 1923 til bulletin XVIII fra Verdensforbundet for Voksenundervisning. Tagore ser samspillet mellem et nyttigt arbejdsliv og et engageret samfundsmæessigt og åndeligt liv som noget helt afgørende - oplysning og ikke guldklumper var kendetegnet for et helt og godt menneskeliv. Frihedstanken var for Tagore blevet afsporet i den indiske politiske elite, der $\mathrm{i}$ stedet for at arbejde for den menneskelige frigørelse fra social og åndelig nød af folkemasserne $\mathrm{i}$ de indiske landdistrikter samlede sig om at bekæmpe det engelske herredømme. Reelt overså eliten betydningen af den kulturelle arv for en indre selvbevidsthed og følelse af eget menneskeværd, som bør gå forud for eller vekselvirke med ydre politisk frihed og selvstændighed. Voksenundervisningen måtte $\mathrm{i}$ den indiske virkelighed bygge på den bevidstgjorte sociale erfaring gennem handling - dvs mearning by doing $\mathrm{k}$.

Mukherjee betoner, at Grundtvigs betydning gennem højskolens bevidsthedsskabende virke udbredt mundtligt og på modersmålet også spillede tilbage på samfundsudviklingen og den danske gårdmandsklasses evne til produktionsmæssig modernisering bl.a. gennem samarbejde og andelsbevægelsens virksomheder. Det er bl.a. denne erfaring om vekselvirkningen mellem på den ene side de åndelige og kulturelle forhold og på den anden side hverdagens produktionsliv, som forbinder såvel Tagores og Grundtvigs tankeverden som deres virkningshistorie især vedrørende de brede befolkningslag i landdistrikterne. Helt konkret er denne ideologiske og praktiske parallelisering blevet fortsat, bl.a. ved at medarbejdere fra organiseringen af det praktiske virke $i$ de indiske landdistrikter løbende kommer på danske og nordiske højskoler. Grundet fattigdommen må i Indien højskolen komme til landsbyen og ikke omvendt, dvs at lærerne må undervise $\mathrm{fx}$ i de mange forsamlingshuse, ligesom kvindernes inddragelse, der er af yderste vigtighed, kun da vil kunne lade sig gøre. Store fremskridt er gjort og resultaterne kan ses i hundreder af landsbyer. Sluttelig sættes Grundtvig ind på linie med Tagore og Gandhi $i$ et verdenshistorisk perspektiv, som befordrere af ægte menneskelig værdighed og selvrespekt gennem voksenuddannelsesbevægelse byggende på befolkningernes aktive medvirken på egne betingelser og ikke presset ned over dem fra elitært og centralistisk hold.

I en kort beretning fra Afrika vises (s. 204-05), at landsbyen ikke blot mentalt, men også reelt lever videre blandt de mange millioner, som i disse år fra landdistrikterne søger til de afrikanske storbyer. Kontakterne er tætte og ofte opretholder storbyboen en bolig i landsbyen. Landsbykulturens forestillingsverden og linserfaringer derfra er så vigtige i dagligdagen, at man skal vare sig for ved *fejldisponeret« uddanneise at hindre reelle fremskridt. Kun hvor åndelig og materiel udvikling, som de bør, kan følges ad og veksetvirke, sker der varige og 
positive forandringer. Såvel tyske som danske højskolefolk har i samarbejde med lokale kræfter med held virket for at omsætte dele af højskoleverdenens teori og praksis til den afrikanske virkelighed.

\section{Grundtrig og Island, - filologien}

Fra det 19. århundredes første årtier var Grundtvig sammen med filologen Rasmus Rask helt centrale $\mathrm{i}$ den nordiske genopdagelse og udbredelse af kendskabet til den norrøne kulturarv fra Island. Rask blev, anfører Jürgen v. Heymann(s. $291 \mathrm{f}$ ), en foregangsfigur $\mathrm{i}$ islændingenes vej mod kulturel og national selustændighed. Trods en livslang og imponerende indsats for værdierne $i$ den islandske kulturarv er i Island Grundtvig og hans betydning blevet overset. Dette hænger antagelig sammen med, at Grundtvig konstant fremhævede det mundtlige ords forrang for det skrevne, hvorved han indirekte nedprioriterede det for den islandske kulturelle nationalbevægelse centrale: de norrøne skrifter. Samtidig hermed hævdede han den historisk-poetiske holdnings førende plads i modsætning til den islandske elites insisteren på det historisk-politiske plans dominans.

Grundtvigs højskoleideer blev p̊̊ Island indført af den poetisk-sværmeriske Gudmundur Hjaltasson, som vel ikke var den store praktiker, men dog i tre år drev en højskole, der var billig for eleverne, og som var rimeligt vel besøgt. Hjaltasson og hans højskole blev af den politisk-kulturelle elite udsat for den form for syredrivende og menneskeødelæggende spot, som islandske intellektuelle er mestre i. Egentlig må denne totalt negative reaktion ifølge Heymann undre, da en grundtvigsk højskole efter sit koncept måtte støtte den nationale bevægelse. Dette, forekommer det mig, er kun en detvis rigtig iagttagelse, idet en højskole meget vel kunne støtte en national linie, men med tiden måske ville vende sig mod bevægelsens elite. Denne elite havde efter min mening nok så meget tilfælles med mange danske nationalliberales åndshovmod (blot på islandsk baggrund) som med de $\mathrm{i}$ islandske småbønders dagligdag og velfærd, der lå Hjaltasson på hjerte. - Andre tog senere højskoleideen op, og til 1931 fandtes der i Island to højskoler. Disse afløstes af mere fagligt betonede og eksamensrettede landbrugsskoler, hvor en del af højskoleverdenens kulturelle praksis dog blev indført. Uden større ideologisk overbygning slog andelsbevægelsen igennem på en række områder. Der rejstes med tiden ud over Island mange forsamlingshuse, hvor et folkeligt kulturliv delvis i grundtvigsk ånd fandt en ramme, ligesom andre elementer fra den rige arv udfoldedes inden for de brede ungdomsbevægeiser. Det offentlige islandske skolesystem udvikledes stærkt og ofte påvirket af dansk-norsk paedagogisk teori og praksis; men først 1972 fik man i Island en mindre folkehøjskole i Skálholt.

De mere litteraturhistoriske og filologiske indlæg er primært skrevet af danske bidragydere, hvorfor jeg herom henviser til temareferencerne forrest.

\section{Grundtrig og tysk teologi}

Også i de teologiske afsnit er flere af de interessante og vægtige bidrag skrevet af danske, hvorfor jeg blot må henvise til temareferencerne foran. 
Professor Henning Schröer fra Bonn anfører (s. 219 f), at i de tyske lærebøger til det teologiske studium er Grundtvig kun perifert behandlet. Alene Emanuel Hirsch i sin „Geschichte der neueren evangelischen Theologie«, Gütersloh 1968, giver en rimelig introduktion. Den ideologiske tilbageholdenhed over for

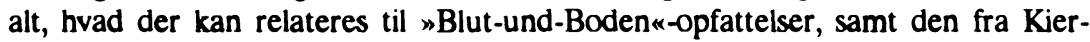
kegaard velkendte kritiske holdning til Grundtvig har samlet stået hindrende i vejen for en bredere accept af dennes betydning. Schroer finder, at Grundtvig kan og bør inddrages i tysk teologi og kirkeliv på flere felter: Vedrørende levende og livsnær teologi, liturgi og menighedsvirke samt omkring fornyelse af salmeudvalget og en forståelse af det tresidede samspil mellem myte og et levende folkesprog og et levende kirkesprog. Pædagogisk er Grundtvigs frihedsbegreb (åbenhed) vigtigt i den løbende debat om dels relationerne mellem sandhed og pluralitet $i$ kirken, dels faren fra de to yderligheder for kirken $i$ sækularisering kontra sakralisering. Poesi, fantasi og mundtlighed er ifølge Schröer centrale elementer fra Grundtvig og den grundtvigske arv at inddrage i den tyske kirkes didaktik.

\section{Afsluttende bemaerkninger}

Tager læseren i betragtning, at jeg end ikke er kommet nærmere ind på halvdelen af denne vægtige fremlæggelse, bliver det klart, at vi her har fået et vigtigt redskab i hænde for også i den danske debat at kunne sætte Grundtvig og hans virkningshistorie $i$ international sammenhæng.

Indledende bemærkede jeg, at det trods al respekt for Grundtvigs eget virke er hans virkningshistorie i højskolen, i kirkelivet, i frihedsforståelsen, i den politiske kultur, i respekten for modersmålet og for mundtligheden og for den folkelige kultur, som har betydning uden for det danske sociale og kulturelle rum. Dette synspunkt har bogen fra et utal af vinkler bekræftet - det er den grundtvigske arvs nytte $\mathrm{i}$ den kulturelle og sociale praksis, som er væsentlig internationalt set.

Konferencens forløb og bogens mange artikler har vist, at Grundtvig som digter, sprogforsker og kirkemand har mindre gennemslagskraft udadtil end hans folkeligt-demokratiske og pæedagogiske grundtanker og virke.

Konsekvenserne for os i Danmark af de mange indlæg bør give sig udtryk p̊̊ tre hovedfelter:

For det furste, vi har en forpligtelse til ved gode antologier på de førende sprog at stille Grundtvigs tankeverden til rådighed for den ovrige verden, dvs teorien skal synligeres (en tysksproget antologi er på vej); parallelt hermed må vi på mange sprog beskrive og forklare hans virkningshistorie $i$ den danske kontekst som eksempel på anvendeliggørelse af hans visioner, dvs praksis skal synligg res (jvf. fx flere udmærkede editioner fra Det danske Selskab). Dette kan kun ske på kvalificeret vis, hvis vi i Danmark sikrer, at en levende og engageret grundtvigforskning og studier $i$ de folkelige livsformer har gode vilkår, dvs penge og forskere. - Herunder må vi gøre et alvorligt stykke formidlingsarbejde for at vise, at for Grundtvig hang menneskelivet og kristenlivet $i$ det universelle 
perspektiv sammen, samtidig med at han fandt, at man på det samfundsmæessige plan ikke skulle blande statsmagt og trosliv sammen.

For det andet, vi må i endnu højere grad, end det allerede sker, ved stipendier til højskoleophold og studiebesøg for udlændinge, ved rejsestøtte og ved støtte til udsendelse af konsulenter og gæstelærere bidrage til den oplevelsesdimension vedr. de folkelige oplysnings- og uddannelsesformer, som de fremmede så åbenlyst efter mange indlæg ikke kan læse sig til.

For det tredje, vi må politisk og gennem den offentlige debat og institutionelt sikre, at Danmark fortsat kan være det konstruktive paedagogiske laboratorium med den kulturelle og lokalt stærke uregerlighed i form af det permanente oprør mod alt åndeligt og kulturelt formynderi og centralstyring, som så mange indlæg direkte og indirekte har peget på, er den egentlige styrke i den grundtvigske arv. Nok skal vi danske, som hidtil, til stadighed være i dialog med det bedste $\mathrm{i}$ udlandets tænkning og praksis, men vi skal vekselvirke dermed ud fra en styrkens position og en velbegrundet bevidsthed om eget værd og ikke hovedløst underkaste os udlandets centralistiske og ofte menneskefjendske institutionelle traditioner eller deres nyeste modestrømninger i pædagogik og kultur.

Mange af de udenlandske bidragydere har hæftet sig ved, at man hos Grundtvig setv og i den grundtvigske arv i hverdagens Danmark bevidst og med held forenede teori og praksis, at videnskab og folkelighed på det holdningsmæssige plan kunne gå hånd $\mathrm{i}$ hånd, og at enkeltmennesket og lokalsamfundet $\mathrm{og}$ institutionen (skolen, frikirken osv) skulle være i dialog med storsamfundet og centralstyret, men ikke burde være underkastet disse. Var der end tale om ideelle fordringer, så var det dog lykkedes i langt højere grad i Danmark end de fleste andre steder at nærme sig en opfyldelse deraf.

I tysk arbejderkulturs voksenundervisning, i Tagores tænkning og i afrikansk landsbykultur mv kan der efter indlæggene for mig at se være nok så meget pædagogisk og kulturel grokraft at vekselvirke med som i amerikansk computoriseret undervisningsprogrammel, i multibel-choice eksaminer eller EFs Erasmus-programmer for studenterudveksling.

De mange bidrag vækker til eftertanke om, hvilke menneskelige og samfundsmæessige værdier, vi måske tager som alt for setvfølgelige i dagens Danmark. Et udblik til det tidligere Jugoslavien, til Kaukasus, til Kurdistan osv viser, at en række af de grundæggende værdier for Grundtvig om menneskelivet og samfundslivet ikke er os givet, men til stadighed må tilkæmpes og fornys. Dette handler denne bog også om. 


\section{Noter}

1 Blandt mange muligheder har jeg vedr. Grundtvigs uforståelighed i datidens Danmark valgt hans mangeårige og kritiske bekendte, biskop $H$. Martensen, „Af mit Levnet火, I-III, Kbh. 1882-83. - Del II, s. 59, om Grundtvigs salmer, meget "var til Anstød, Smagløsheder, Besynderligheder og Dunkelheder i Udtrykket« for borgerskab og præsteskab. Del I, s. 53 hedder det om Grundtvig som prædikant for det dannede borgerskab »...Grundtvig kunde ikke føde dem, da han ikke kunde tiltale de dannede; i hvert Fald kunde han det ikke dengang . Del II, s. 59, Grundtvig udtrykte direkte om sine prædikener, at han måtte skrive dem ned "da han ellers ikke var sikker paa at træffe det rette folkelige Udtryk . Del II, s. 64, Martensen havde meget tilovers for G.s salmedigtning med dens "poetiske Kraft, Rigdom og Fylde ${ }_{\kappa}$, hvor han var større end Kingo og Brorson, men mente, wat han som Salmedigter aldrig saaledes vil kunde gaae ind i Folket som disse $\kappa_{.}$

2 V. Wahlin: „Skolevirke og trosliv, bd. I. Bevægelse, vækkelse, oplysning, uddannelse gennem 100 år. Historie og virke for ungdoms- og voksenskoler med baggrund i Indre Mission, KFUM og KFUK, FDF/FDP m.fl.«, s. 1721. Aarhus 1991.

Redaktionen af »Grundtvig-Studier « har fået tilsendt det store firebindsværk om Dansk Identitet, der på initiativ af Københavns Universitet og under redaktion af professor, dr. phil. Ole Feldbaek er fremkommet på Reitzels Forlag i årene 1991-92, samt professor dr. oecon P. Nyboe Andersens nyligt udkome bog om Hal Koch og Krogerup.

Begge publikationer, der $\mathrm{i}$ mange henseender har relationer til Grundtvigs liv og virke, vil blive anmeldt $\mathrm{i}$ »Grundtvig-Studier« 1994. 